\title{
KONSEP PENILAIAN KINERJA GURU DAN FAKTOR YANG MEMPENGARUHINYA
}

\author{
LA ODE ISMAIL AHMAD \\ Fakultas Tarbiyah dan Keguruan \\ Universitas Islam Negeri Alauddin Makassar
}

\begin{abstract}
:
Law Number 20 Year 2003 on National Education System, Law Number 14 Year 2005 regarding Teachers and Lecturers, and Government Regulation Number 19 Year 2005 on National Education Standard states teachers are professional educators. Teachers as professionals have an important role in learning. The role of teachers in learning is to make learning design, organizing teaching and learning activities, teaching or learning. Efforts have been made to improve the quality of national education, such as the development of national and local curricula, improving teacher competence through training, procurement of books and instructional tools, teacher certification, procurement and improvement of educational facilities and infrastructure, and improving school management. But apparently all these efforts have not shown maximum results. Proven when people are still talking about less qualified graduates, even in terms of morals learners tanpak increasingly degenerate, honesty is very lacking, no manners, less discipline, less responsibility, shyness is very lacking, misconduct everywhere, and so on. In order to achieve the targeted goals in improving the quality of education, this is where the importance of teachers improve the quality of their performance in learning as a figure that plays an important role in advancing the world of education. To have a good performance teachers are required to have adequate academic ability, and can apply the knowledge they have to learners to advance the quality of learning learners.
\end{abstract}

Keywords: The Concept of Assessment, Teachers, Education System

\section{Pendahuluan}

ujuan utama pendidikan mengarah kepada pengembangan dan
pemberdayaan potensi manusia (Nata, 2001:13), sehingga dapat menjadi
manusia yang berperadaban, menjaga solidaritas, tulus dalam bekerja kemanusian. Oleh karena itu, pendidikan perlu ditata dengan baik, agar dapat berjalan efektif dan efisien untuk mencapai tujuan. Peraturan Pemerintah RI Nomor 19 Tahun 2005 tentang Standar Nasional Pendidikan (SNP) mengamanatkan dalam Bab 1 Pasal 1 ayat 9 disebutkan bahwa:

Standar Pengelolaan Pendidikan Nasional adalah standar nasional pendidikan yang berkaitan dengan perencanaan, pelaksanaan, dan pengawasan kegiatan pendidikan pada tingkat satuan pendidikan kabupaten/kota, propinsi atau nasional agar tercapai efisiensi dan efektivitas penyelenggarakan pendidikan (Departemen Pendidikan, 2005:69). 
Mutu pendidikan sering diartikan sebagai karakteristik jasa pendidikan yang sesuai dengan kriteria tertentu untuk memenuhi kepuasan pengguna (user) pendidikan, yakni peserta didik, orang tua, serta pihak-pihak berkepentingan lainnya. Dalam menjaga mutu proses tersebut, diperlukan adanya quality control yang mengawasi jalannya proses dan segala komponen pendukungnya.

Kualitas pendidikan, terutama ditentukan oleh proses belajar mengajar tersebut guru memegang peran yang penting. harus diakui bahwa guru adalah kreator proses belajar mengajar. la adalah orang yang akan mengembangkan suasana bebas bagi peserta didik untuk mengkaji apa yang menarik dan mampu mengekspresikan ide-ide dan kretivitasnya dalam batas-batas norma-norma yang ditegakkan secara konsisten. Meskipun fasilitas pendidikan lengkap dan canggih, namun bila tidak ditunjang oleh keadaan guru yang berkualitas, maka mustahil akan menimbulkan proses belajar dan pembelajaran yang maksimal (Utami, http:// www.pikiran-rakrat.com/cetak /102/150802/htm).

Oleh karena itu, guru harus selalu disupervisi dalam konteks kualitas kinerjanya sehingga dapat berbanding lurus dengan fungsinya untuk meningkatkan kualitas mutu pendidikan. Meskipun guru bukanlah satu-satunya faktor yang menentukan mutu sebuah lembaga pendidikan.

\section{Penilaian Kinerja}

Salah satu tugas manajer atau kepala sekolah terhadap guru salah satunya adalah melakukan penilaian atas kinerjanya. Penilaian ini mutlak dilaksanakan untuk mengetahui kinerja yang telah dicapai oleh guru, baik, sedang, atau kurang. Penilaian ini penting bagi setiap guru dan berguna bagi sekolah dalam menetapkan kegiatannya. Penilaian kinerja/ prestasi menurut Hasibuan adalah kegiatan manajer untuk mengevaluasi prestasi kerja karyawan serta menetapkan kebijaksanaan selanjutnya (Malayu, 1999:87).

Sehubungan dengan hal di atas, maka penilaian kinerja guru harus berdasarkan Standar Kompetensi Guru. Dalam bukunya yang berjudul Guru sebagai Profesi, Suparilan mengatakan bahwa standar kompetensi guru dapat diartikan sebagai "suatu ukuran yang ditetapkan atau dipersyaratkan". Lebih lanjut dinyatakan bahwa Standar Kompetensi Guru adalah suatu ukuran yang ditetapkan atau dipersyaratkan dalam bentuk penguasaan pengetahuan dan perilaku perbuatan bagi seorang guru agar berkelayakan untuk menduduki jabatan fungsional sesuai dengan bidang tugas, kualifikasi dan jenjang pendidikan. Berdasarkan pengertian tersebut, standar kompetensi guru dibagi dalam tiga komponen yang saling terkait, yaitu:
a) Pengelolaan pembelajaran
b) Pengembangan profesi, dan
c) Penguasaan akademik. 
Ketiga komponen standar kompetensi guru tersebut, masing-masing terdiri atas beberapa kompetensi, komponen pertama terdiri atas empat kompetensi, komponen kedua memiliki satu kompetensi, dan komponen ketiga terdiri atas dua kompetensi. Dengan demikian, ketiga komponen tersebut secara keseluruhan meliputi 7 (tujuh) kompetensi dasar, yaitu:

a) Penyusunan rencana pembelajaran

b) Pelaksanaan interaksi belajar- mengajar

c) Penilaian prestasi belajar peserta didik

d) Pelaksanaan tindak lanjut hasil penilaian prestasi belajar peserta didik

e) Pengembangan profesi

f) Pemahaman wawasan kependidikan

g) Penguasaan bahan kajian akademik sesuai dengan mata pelajaran yang diajarkan (Peraturan Pemerintah RI No. 19,2005:25).

Sedangkan menurut Agus Sunyato dalam bukunya Anwar Prabu Mangkunegara mengemukakan bahwa sasaran sasaran dan penilaian kinerja karyawan sebagai berikut:

a) Membuat analisa kinerja dari waktu yang lalu secara berkesinambungan dan periodik, baik kinerja karyawan maupun kinerja organisasi.

b) Membuat evaluasi kebutuhan pelatihan dari para karyawan melalui audit keterampilan dan pengetahuan sehingga dapat mengembangkan kemampuan dirinya.

c) Menentukan sasaran dari kinerja yang akan dating dan memberikan tanggung jawab perorangan sehingga untuk periode selanjutnya jelas apa yang harus diperbuat oleh karyawan, mutu dan baku yang harus dicapai.

Menemukan potensi karyawan yang berhak memperoleh promosi, dan mendasarkan hasil diskusi antara karyawan dengan pimpinannya itu untuk menyusun suatu proposal lainnya, seperti imbalan. Jadi, penilaian kinerja merupakan sarana untuk memperbaiki mereka yang tidak melakukan tugasnya dengan baik di dalam organisasi.

Dalam organisasi pencapaian sasaran suatu kedudukan yang terbaik dan terpercaya dalam bidangnya sangat bergantung kepada para pelaksanaannya, yaitu para karyawan (Mangkunegara, 2004:67).

\section{Faktor-Faktor yang Mempengaruhi Kinerja}

Menurut Anwar Prabu Mangkunegara, faktor yang mempengaruhi kinerja guru adalah faktor kemampuan (ability) dan faktor motivasi (motivision) (Mangkunegara, 2004:67).

a) Faktor kemampuan

Secara psikologi, kemampuan guru terdiri dari kemampuan potensi (IQ) dan kemampuan reality (knowledge+skill). Artinya seorang guru yang memiliki latar 
belakang pendidikan yang tinggi dan sesuai dengan bidangnya serta terampil dalam mengerjakan pekerjaan sehari-hari, maka ia akan lebih mudah mencapai kinerja yang diharapkan. Oleh karena itu, pegawai perlu ditetapkan pada pekerjaan yang sesuai dengan keahliannya. Dengan penempatan guru yang sesuai dengan bidangnya akan dapat membantu dalam efektivitas suatu pembelajaran.

b) Faktor motivasi

Motivasi terbentuk dari sikap seorang guru dalam menghadapi situsi kerja. Motivasi merupakan kondisi yang menggerakkan seseorang yang terarah untuk mencapai tujuan pendidikan. C. Meclelland mengatakan dalam bukunya Anwar Prabu berpendapat bahwa ada hubungan yang fositif antara motif berprestasi dengan pencapaian kinerja (Mangkunegara, 2004:68). Dalam dunia psikologi, masalah motivasi ini selalu mendapat perhatian khusus oleh para ahli. Karena motivasi itu sendiri merupakan gejala jiwa yang dapat mendorong manusia untuk bertindak atau berbuat sesuatu keinginan dan kebutuhan.

Motivasi merupakan kekuatan energi, penopang/penyokong dalam melakukan sesuatu untuk mencapai tujuan yang ingin dicapai (Paul, Kauchak, 1997 :341). Syah mengemukakan bahwa motivasi ialah keadaan internal organisme, baik manusia maupun hewan yang mendorongnya untuk berbuat sesuatu. (Syah, 2001 :136). Dalam hal ini, motivasi berarti pemasok daya untuk bertingkah laku secara terarah. Sementara itu Sabri mengartikan motivasi sebagai segala sesuatu yang menjadi pendorong timbulnya suatu tingkah laku. Hal tersebut sejalan dengan Suryabrata yang mengemukakan bahwa motivasi adalah keadaan dalam pribadi orang yang mendorong individu untuk melakukan aktivitas-aktivitas tertentu guna mencapai suatu tujuan (Sabri 1996 :85).

Dalam ajaran Islam, motivasi kerja ini sangat terkait dengan niat. Yaitu Islam mengajarkan bahwa kerja sangat ditentukan oleh niat yang mendasarinya. Seseorang sangat mungkin akan memperoleh apa yang diharapkan jika dilakukan dengan sungguh-sungguh dan sesuai dengan ketentuan yang berlaku. Rasulullah saw. bersabda:

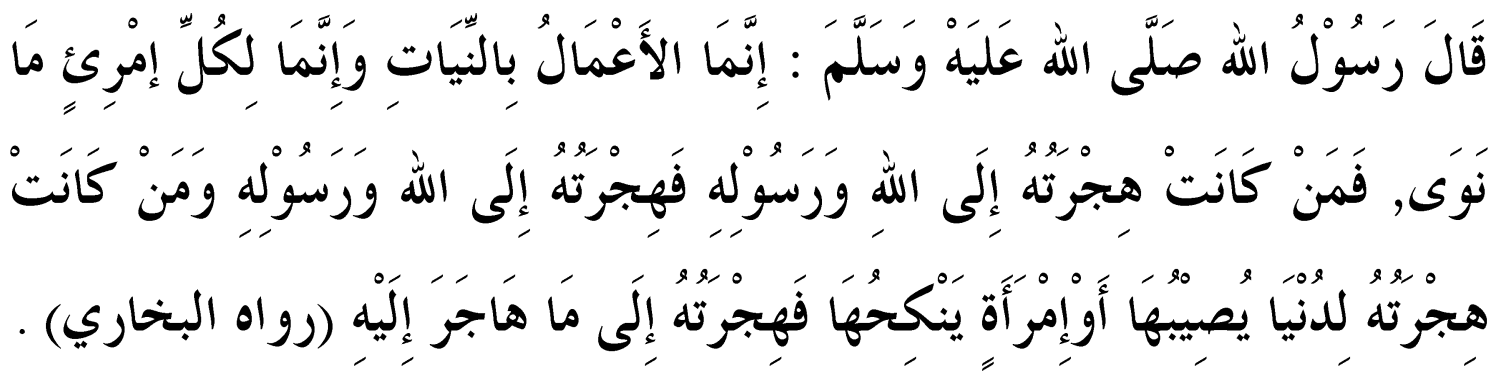

Artinya:

Rasulullah Saw bersabda: Sesungguhnya setiap amalan itu bergantung kepada niat. Sesungguhnya setiap orang itu akan mendapat sesuatu sesuai dengan niatnya. Siapa yang berhijrah karena Allah dan rasulNya, maka hijrahnya itu karena Allah dan RasulNya. Siapa yang berhijrah untuk mendapatkan dunia dia akan 
mendapatkan atau karena perempuan yang ingin dikawininya, maka hijrahnya itu mendapatkan apa yang diniatkan (HR. Bukhari)

Hadis di atas menggambarkan bahwa kerja itu sangat dipengaruhi oleh motivasi yang mendasarinya. Seorang yang hijrah karena motivasi dunia dan wanita, maka ia akan mendapatkannya. Dan siapa yang hijrah karena Allah dan RasulNya, maka hijrahnya itu akan diterima oleh Allah dan Rasulnya (al-Asqalani, 1992:15). Demikian pula halnya dalam proses belajar mengajar, seorang guru akan memperoleh sesuatu sesuai dengan motif yang mendasarinya dalam bekerja.

Pentingnya mendasari kerja itu dengan niat yang baik dikarenakan dalam pandangan Islam, kerja dianggap sebagai sesuatu yang mulia. kerja dianggap sebagai ibadah dan memang manusia diciptakan semata-mata untuk beribadah kepada Tuhan. Sebagai ibadah, kerja itu haruslah dilandasi dengan motivasi yang tulus dan ikhlas.

Guru sebagai pendidik memiliki tugas dan tanggung jawab yang berat. Guru harus menyadari bahwa ia harus mengerjakan tugasnya tersebut dengan sungguhsungguh, bertanggung jawab, ikhlas dan tidak asal-asalan, sehingga siswa dapat dengan mudah menerima apa saja yang disampaikan oleh gurunya. Jika ini tercapai, maka guru akan memiiki tingkat kinerja yang tinggi.

Guru mempunyai peranan penting dalam pengembangan diri anak dengan memberikan berbagai macam pengetahuan dan keterampilan serta pembentukan kepribadian. Oleh karena itu, guru dituntut mempersiapkan berbagai kemampuan dalam melaksanakan pendidikan dan bimbingan kepada peserta didik dengan menolong mereka agar dapat mandiri mencapai kedewasaan. Kemampuan yang harus dimiliki oleh guru dalam kegiatan pembelajaran di antaranya adalah kemampuan profesional yang meliputi penguasaan materi pembelajaran, strategi pembelajaran, penguasaan metode, penguasaan bimbingan dan penyuluhan serta penguasaan evaluasi pembelajaran (Nasution, 2003:12).

Sebagai pengelola pembelajaran, guru harus mampu mengelola seluruh proses kegiatan pembelajaran dengan menciptakan kondisi-kondisi belajar yang sedemikian rupa sehingga setiap peserta didik dapat belajar secara efektif dan efisien. Dalam fungsinya sebagai penilai hasil belajar, seorang guru hendaknya secara terus-menerus mengikuti hasil belajar yang telah dicapai oleh peserta didik dari waktu ke waktu. Informasi yang diperoleh melalui evaluasi ini akan dijadikan sebagai umpan balik dan titik tolak untuk memperbaiki dan meningkatkan proses pembelajaran dalam mencapai prestasi belajar peserta didik.

Selanjutnya Mac Leland mengemukakan 6 krakteristik dari guru yang memiliki motif berprestasi tinggi yaitu:

a) Memiliki tanggung jawab pribadi tinggi

b) Berani mengambil resiko

c) Memiliki tujuan yang realistis 
d) Memanfaatkan rencana kerja yang menyeluruh dan berjuang untuk merealisasi tujuannya.

e) Memanfaatkan umpan balik yang kongkret dalam seluruh kegiatan kerja yang dilakukannya.

f) Mencari kesempatan untuk merealisasikan rencana yang telah diprogramkan (Nasution, 2003:68).

Membicarakan kinerja mengajar guru, tidak dapat dipisahkan faktor-faktor pendukung dan pemecah masalah yang menyebabkan terhambatnya pembelajaran secara baik dan benar dalam rangka pencapaian ujuan yang diharapkan guru dalam mengajar.

Adapun faktor yang mendukung kinerja guru dapat digolongkan ke dalam dua macam yaitu:

a) Faktor dari dalam sendiri (intern) yang meliputi:

1) Kecerdasan

Kecerdasan memegang peranan penting dalam keberhasilan pelaksanaan tugas-tugas seorang pendidik dalam proses pembelaajran. Semakin rumit dan makmur tugas-tugas yang diemban makin tinggi kecerdasan yang diperlukan. Seseorang yang cerdas jika diberikan tugas yang sederhana dan monoton mungkin akan terasa jenuh dan akan berakibat pada penurunan kinerjanya.

2) Keterampilan dan kecakapan;

Keterampilan dan kecakapan orang berbeda-beda. Hal ini dikarenakan adanya perbedaan dari berbagai pengalaman dan latihan.

3) Bakat

Penyesuaian antara bakat dan pilihan pekerjaan dapat menjadikan seseorang bekarja dengan pilihan dan keahliannya.

4) Kemampuan dan minat

Syarat untuk mendapatkan ketenangan kerja bagi seseorang adalah tugas dan jabatan yang sesuai dengan kemampuannya. Kemampuan yang disertai dengan minat yang tinggi dapat menunjang pekerjaan yang telah ditekuni.

5) Motif

Motif yang dimiliki dapat mendorong meningkatkannya kerja seseorang.

6) Kesehatan

Kesehatan dapat membantu proses bekerja seseorang sampai selesai. Jika kesehatan terganggu maka pekerjaan terganggu pula.

7) Kepribadian

Seseorang yang mempunyai kepribadian kuat dan integral tinggi kemungkinan tidak akan banyak mengalami kesulitan dan 37 
menyesuaikan diri dengan lingkungan kerja dan interaksi dengan rekan kerja yang akan meningkatkan kerjanya.

8) Cita-cita dan tujuan dalam bekerja

Jika pekerjaan yang diemban seseorang sesuai dengan cita-cita maka tujuan yang hendak dicapai dapat terlaksanakan karena ia bekerja secara sungguh-sungguh, rajin, dan bekerja dengan sepenuh hati.

b) Faktor dari luar diri sendiri (ekstern)

Yang termasuk faktor dari luar diri sendiri (ekstern) diantaranya:

1) Lingkungan keluarga

Keadaan lingkungan keluarga dapat mempengaruhi kinerja seseorang. Ketegangan dalam kehidupan keluarga dapat menurunkan gairah kerja.

2) Lingkungan kerja

Situasi kerja yang menyenangkan dapat mendorong seseorang bekerja secara optimal. Tidak jarang kekecewaan dan kegagalan dialami seseorang di tempat ia bekerja. Lingkungan kerja yang dimaksud di sini adalah situasi kerja, rasa aman, gaji yang memadai, kesempatan untuk mengembangan karir, dan rekan kerja yang kologial.

3) Komunikasi dengan kepala sekolah

Komunikasi yang baik di sekolah adalah komunikasi yang efektif. Tidak adanya komunikasi yang efektif dapat mengakibatkan timbulnya salah pengertian.

4) Sarana dan prasarana

Adanya sarana dan prasarana yang memadai membantu guru dalam meningkatkan kinerjanya terutama kinerja dalam proses mengajar mengajar (Kartini, 1985:22).

5) Kegiatan guru di kelas

Peningkatan dan perbaikan pendidikan harus dilakukan secara bertahap. Dinamika guru dalam pengembangan program pembelajaran tidak akan bermakna bagi perbaikan proses dan hasil belajar siswa, jika manajemen sekolahnya tidak memberi peluang tumbuh dan berkembangnya kreatifitas guru. Demikian juga penambahan sumber belajar berupa perpustakaan dan laboratorium tidak akan bermakna jika manajemen sekolahnya tidak memberikan perhatian serius dalam mengoptimalkan pemanfaatan sumber belajar tersebut dalam proses belajar mengajar. Menurut Dede Rosyada dalam bukunya Paradigma Pendidikan Demokratis bahwa kegiatan guru di dalam kelas meliputi:

a) Guru harus menyusun perencanaan pembelajaran yang bijak.

b) Guru harus mampu berkomunikasi secara efektif dengan siswasiswanya 
c) Guru harus mengembangkan strategi pembelajaran yang membelajarkan

d) Guru harus menguasai kelas

e) Guru harus melakukan evaluasi secara benar (Rosyada, 2004:122).

6) Kegiatan guru di sekolah antara lain yaitu:

Berpartisipasi dalam bidang administrasi, di mana dalam bidang administrasi ini para guru memiliki kesempatan yang banyak untuk ikut serta dalam kegiatan-kegiatan sekolah antara lain:

a) Mengembangkan filsafat pendidikan

b) Memperbaiki dan menyesuaikan kurikulum

c) Merencanakan program supervisi

d) Merencanakan kebijakan-kebijakan kepegawaian (Purwanto, 2003:144-150).

Semua pekerjaan itu harus dikerjakan bersama-sama antara guru yang satu dengan yang lainnya yaitu dengan cara bermusyawarah. Untuk meningkatkan kinerja, para guru harus melihat pada keadaan pemimpinnya (kepsek). Jadi, dapat disimpulkan bahwa baik dan buruknya guru dalam proses belajar mengajar dipengaruhi oleh beberapa faktor salah satunya adalah supervisor dalam melaksanakan pengawasan atau supervisi terhadap kemampuan (kinerja guru).

\section{PENUTUP}

Undang-undang RI Nomor 20 Tahun 2003 tentang Sistem Pendidikan Nasional (UU RI No. 20, 2003:6), Undang-undang RI nomor 14 Tahun 2005 tentang Guru dan Dosen (UU No. 14, 2005:8), dan Peraturan Pemerintah RI Nomor 19 Tahun 2005 tentang Standar Nasional Pendidikan menyatakan guru adalah pendidik professional. Guru sebagai tenaga profesional memiliki pran penting dalam pembelajaran. Peran guru dalam pembelajaran adalah membuat desain pembelajaran, penyelenggaraan kegiatan belajar mengajar, bertindak mengajar atau membelajarkan (Daryanto, 2005:5).

Berbagai usaha telah dilakukan untuk meningkatkan mutu pendidikan nasional, misalnya pengembangan kurikulum nasional dan lokal, meningkatkan kompetensi guru melalui pelatihan, pengadaan buku dan alat pelajaran, sertifikasi guru, pengadaan dan perbaikan sarana dan prasarana pendidikan, serta meningkatkan mutumanajemen sekolah.

Namun tampaknya segala usaha tersebut belum menunjukkan hasil yang maksimal. Terbukti ketika masyarakat masih membicarakan lulusan sekolah kurang bermutu, malah dari segi moral peserta didik tanpak kian merosot, kejujuran sangat kurang, sopan santun tidak ada, kurang disiplin, kurang bertanggungjawab, rasa malu sangat kurang, penyelewengan di mana-mana, dan sebagainya. Ini semua adalah produk dan outcome yang diperoleh selama 
bersekolah (Alma, 2009:123-124). Oleh karena itu sebagai kompenen penting dalam proses belajar mengajar harus berperan aktif dan menempatkan kedudukannya sebagai tenaga profesional dalam mengaktualisasikan segala kompetensi yang dimilikinya.

Guna mencapai tujuan yang menjadi target dalam meningkatkan mutu pendidikan, disinilah pentingnya guru meningkatkan kualitas kinerjanya dalam pembelajaran selaku tokoh yang sangat memegang peran penting dalam memajukan dunia pendidikan. Untuk memiliki kinerja yang baik guru dituntut memiliki kemampuan akademik yang memadai, dan dapat mengaplikasikan ilmu yang dimilikinya kepada peserta didik untuk memajukan mutu belajar peserta didik. Hal ini menentukan kemampuan guru dalam menentukan cara menyampaikan materi dan pengelolaan interaksi belajar mengajar.

\section{DAFTAR PUSTAKA}

Alma, Buchari, et al., edisi II., Guru Profesional: Menguasai Metode dan Terampil Mengajar Bandung: Alfabeta, 2009.

Asqalani, Ibn Hajar al-, Fath al-Bary bi Syarh Sahih al-Bukhari, Beirut: Dar al-Fikr, 1992.

Bukhari, Al-Imam Abu 'Abdullah Muhammad bin Isma'il al-, Sahih al-Bukhari Riyad : Dar al-Salam, 1997.

Daryanto, Administrasi Pendidikan Cet. III; Jakarta: Rineka Cipta, 2005.

Departemen Pendidikan Nasional, Peraturan Pemerintah Nomor 19 Tahun 2005 tentang Standar Pendidikan Nasional, Jakarta: 2005.

Eggen, Paul and Don Kauchak. Educational Psychology, Windows on Classroom. New Jarsey: Prentice Hall, Inc., 1997.

Kartini, Kartono, Menyiapkan dan Memadukan Karir Jakarta: CV Rajawali, 1985.

Malayu, Hasibuan SP, Organisasi dan Motivasi Jakarta: Bumi Aksara, 1999.

Mangkunegara, Anwar Prabu, Manajemen Sumber Daya Manusia Perusahaan Bandung: PT. Remaja Rosdakarya, 2004.

Nasution, Berbagai Pendekatan dalam Proses Belajar dan Mengajar Jakarta: Bumi Aksara, 2003.

Nata, Abuddin, Paradigma Pendidikan Islam, Jakarta: Gramedia, 2001.

Peraturan Pemerintah RI No. 19 Tahun 2005 tentang Standar Nasional Pendidikan, Jakarta CV: Eko Jaya, 2005.

Purwanto, M. Ngalim, Administrasi dan Supervisi Pendidikan, Jakarta: Remaja Rosdakarya, 2003. 
Redaksi Sinar Grafika, Undang-Undang Sistem Pendidikan Nasional, UU RI No. 20 Tahun 2003 Jakarta: Sinar Grafika, 2003.

Republik Indonesia, Undang-undang Nomor 14 Tahun 2005 tentang Guru dan Dosen Bandung: Citra Umbara, 2006.

Rosyada, Dede, Paradigma Pendidikan Demokratis: Sebuah Model Pelibatan Masyarakat dalam Penyelenggaraan Pendidikan Jakarta: PT. Kencana, 2004.

Sabri, M. Alisuf, Psikologi Pendidikan Berdasarkan Kurikulum Nasional. Jakarta : Pedoman IImu Jaya, 1996.

Suryabrata, Sumadi, Psikologi Pendidikan. Jakarta : Raja Grafindo Persada, 1995.

Syah, Muhibbin, Psikologi Pendidikan dengan Pendekatan Baru. Bandung: Remaja Rosdakarya, 2001. 